\title{
Efektifitas Penggunaan Antibiotik Beta Laktam dan Amitraz Topikal pada Demodikosis Lokal
}

\author{
Tri Ayu Kristianty*, Zulfa Ichsanniyati, Anjani Retno Setiawati, Zella Nofitri Efendi, \\ Bagus Satrio Budiharjo, Fathia Ramadhani
}

My Vets Animal Clinic BSD, Jalan Kalimantan Blok F2 No. 32 Bumi Serpong Damai, Tangerang Selatan

\begin{abstract}
ABSTRAK: Demodex canis adalah mikroflora normal komensal pada kulit anjing. Demodex spp. berhabitat di bawah folikel rambut atau kelenjar sebum. Bakteri kokus juga merupakan mikroflora normal pada kulit dan umum ditemukan pada kondisi infeksi kulit. Infeksi bakteri pada kasus demodikosis terjadi sebagai kejadian sekunder. Antibiotik beta laktam merupakan golongan antibiotik pilihan yang digunakan terhadap kasus infeksi bakteri kokus. Amitraz adalah akarisida topikal dan digunakan pada kasus demodikosis. Anjing Golden Retriever berusia 7 tahun datang ke My Vets Animal Clinic Bumi Serpong Damai (BSD) dengan kondisi kedua pipi erythema, pustul, erosi, dan pruritic akibat demodikosis dan infeksi sekunder bakterial. Anjing tersebut diberikan terapi fluralaner oral satu kali untuk satu bulan dan amitraz topikal setiap minggu untuk mengatasi demodikosis. Lesi pada anjing tersebut tidak terlihat berkurang nyata. Terapi antibiotik beta laktam oral kemudian diberikan untuk membantu mengatasi infeksi bakteri yang diduga terjadi sekunder dari demodikosis tersebut dan amitraz topikal diberikan setiap hari pada lesi di kedua pipi tersebut. Terapi ini menunjukkan perbaikan yang nyata dalam 8 hari. Lesi erythe$m a$, pustul, dan erosi semakin berkurang nyata dan lesi pustule sudah menghilang pada pemberian antibiotik hari keempat. Berdasarkan pengamatan, penggunaan antibiotik beta laktam dan amitraz topikal cukup efektif pada kasus demodikosis lokal.

Kata kunci:

amitraz, beta-lactam antibiotic(s), demodex
\end{abstract}

\section{- PENDAHULUAN}

Demodex canis adalah mikroflora normal komensal pada kulit anjing. Demodex spp. berhabitat di bawah folikel rambut atau kelenjar sebum, oleh karena itu metode yang digunakan untuk mendeteksi keberadaannya adalah dengan kerokan kulit (deep scraping) atau trichography (Goth 2014). Mayoritas kasus demodikosis memiliki respon yang bagus terhadap pemberian amitraz sebagai akarisida topikal. Umumnya amitraz diberikan dua kali seminggu, namun pada beberapa kasus, pengobatan dengan amitraz perlu dilakukan setiap hari (Puja 2014).

Bakteri kokus merupakan mikroflora normal pada kulit dan umum ditemukan pada kondisi infeksi kulit. Infeksi bakteri pada kasus demodikosis terjadi sebagai kejadian sekunder. Antibiotik beta laktam merupakan golongan antibiotik pilihan yang digunakan pada infeksi bakteri kokus.

\section{- KASUS DAN PEMBAHASAN}

Anjing Golden Retriever berusia 7 tahun datang ke My Vets Animal Clinic Bumi Serpong Damai (BSD) dengan keluhan luka di wajah. Pemeriksaan fisik selanjutnya menunjukkan kondisi pipi kanan terdapat luka segar, erythema, pustul, dan erosi. Anjing dirawat inap dan terlihat bahwa lesi di pipi tersebut pruritic. Pemeriksaan penunjang berupa kerokan kulit dilakukan untuk melihat jaringan subkutan dan folikel rambut. Kerokan kulit menunjukkan hasil positif adanya parasit Demodex spp. Lesi demodikosis paling umum muncul di wajah walaupun lesi bisa juga muncul di bagian tubuh manapun (Hnilica 2011).

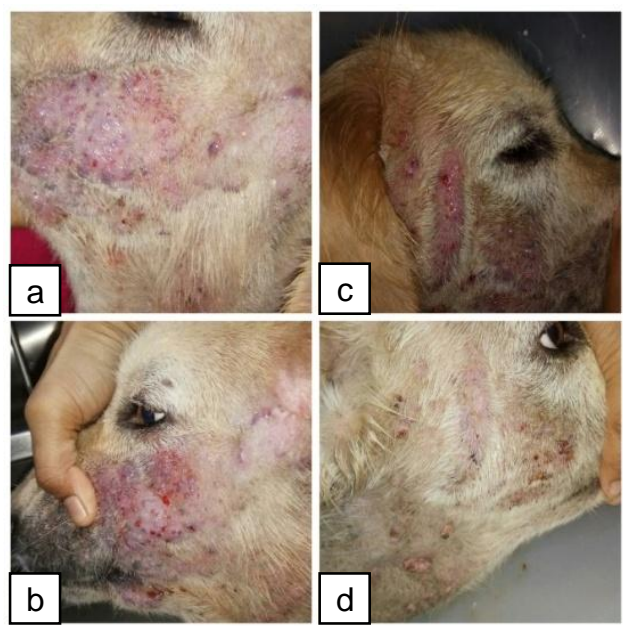

Gambar 1 Perkembangan persembuhan lesio (a) Pipi kiri hari ke 1, (b) pipi kiri hari ke 4, (c) pipi kanan hari ke 1, (d) pipi kanan hari ke 4.

\footnotetext{
Diterima : 28 Juli 2017

Direvisi : 14 Agustus 2017

Disetujui : 16 Agustus 2017
} 
Anjing kemudian diberikan terapi fluralaner oral dan mandi medikasi. Fluralaner oral diindikasikan untuk satu kali pemakaian selama 3 bulan. Mandi medikasi dilakukansatu kali seminggu dengan sampo medikasi yang berisi chlorhexidine gluconate, ketoconazole, keramik, vitamin E, dan ekstrak aloe. Kombinasi bahan aktif pada sampo ini diindikasikan untuk kondisi kulit anjing dengan lesi pruritus, eryhtema, meradang, berkerak, bau tidak sedap, dan alopesia yang disebabkan oleh infeksi bakteri atau jamur.

Lesi pada anjing berkurang, tetapi terlihat tidak nyata dan muncul lesi pada pipi kiri. Lesi yang muncul selain akibat demodikosis, juga diduga terjadi infeksi bakteri sekunder. Terapi antibiotik beta laktam oral kemudian diberikan untuk membantu mengatasi infeksi bakteri sekunder dan amitraz topikal diberikan setiap hari pada lesi di kedua pipi. Terapi ini menunjukkan perbaikan yang nyata dalam 8 hari. Lesi erythema, pustul, dan erosi berkurang nyata dan lesi pustul sudah menghilang pada pemberian antibiotik hari keempat.

\section{- SIMPULAN}

Berdasarkan pengamatan, penggunaan antibiotik beta laktam dan amitraz topikal cukup efektif pada kasus demodikosis lokal.

\section{- INFORMASI PENULIS}

Penulis untuk Korespondensi

felix_ayu@yahoo.com

Persetujuan Penulis

Seluruh penulis telah memberikan persetujuan terhadap versi final naskah ini.

\section{- PUSTAKA ACUAN}

Goth GM. 2014. Canine and Feline Dermatology Atlas. Zaragoza (SP): Servet.

Hnilica KA. 2011. Small Animal Dermatology: A Color Atlas and Therapeutic Guide. Missouri (US): Elsevier.

Puja IK. 2014. Efektivitas ivermectin dengan kombinasi amitraz untuk pengobatan infestasi demodekosis alami pada anjing. Prosiding Konferensi Ilmiah Veteriner Nasional (KIVNAS) Perhimpunan Dokter Hewan Indonesia ke-13. Palembang (IND) 2014. 